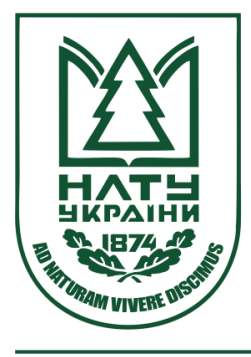

Науковий вісник НЛТУ України Scientific Bulletin of UNFU

ISSN 1994-7836 (print)

http://nv.nltu.edu.ua

https://doi.org/10.15421/40280524

$@ \bowtie$ Correspondence author

Article received 8.05.2018 p.

Article accepted 24.05.2018 p.

D. M. Korinchuk

УДК 620.91:62.818.6

\title{
ВПЛИВ ТЕМПЕРАТУРНОЇ ТА ФІЗИКО-МЕХАНІЧНОЇ АКТИВАЦІЇ БІОМАСИ НА ЕНЕРГОВИТРАТИ ПРОЦЕСУ ПРЕСУВАННЯ БІОПАЛИВ ДЕРЕВИННОГО ТА РОСЛИННОГО ПОХОДЖЕННЯ
}

\begin{abstract}
Досліджено компресійні характеристики пресування подрібненої поліфракційної біомаси рослинного та деревинного походження на прикладі деревини сосни, соломи та лузги соняшника. Встановлено залежності коефіцієнтів основного рівняння пресування від температури пресування та вмісту мікрофракції вторинного подрібнення. Визначено густину гранул, розраховано питому роботу гранулоутворення та досліджено закономірності їх зміни після підвищення тиску, температури та вмісту мікрофракції. Встановлено, що в межах досліджуваного діапазону збільшення тиску температури та вмісту мікрофракції вторинного подрібнення веде до збільшення об'ємної густини гранул біопалива. Водночас підвищення тиску пресування веде до збільшення питомої роботи пресування у 2,2-2,4 раза, а температури та вмісту мікрофракції - до зменшення на $22-46 \%$ та 18-28\%. Встановлено ефект збільшення питомої роботи пресування після переходу від деревинної до рослинної біомаси. Рекомендовано в технологіях виробництва твердого біопалива включати ділянки температурної активації матеріалу перед пресуванням з метою забезпечення температурного режиму пресування не нижче $100{ }^{\circ} \mathrm{C}$ для деревинної біомаси та не нижче $150{ }^{\circ} \mathrm{C}$ для рослинної біомаси, а також ділянки фізико-механічної активації матеріалу шляхом тонкого подрібнення після стадії сушіння не менше $20 \%$ загальної маси матеріалу до мікрофракції зі середнім розміром не більше 200 мкм 3 наступним змішуванням з основною масою та пресуванням або введенням у біомасу мікрофракцію іншого виду біомаси в тих же пропорціях.
\end{abstract}

Ключові слова: робота пресування; енергоефективні режими; мікрофракція; тиск; густина.

Вступ. Відновлювані та альтернативні джерела енергії, до яких відноситься і біомаса, вже не просто предмет для наукових досліджень, а істотний чинник, що створює тиск на ціни традиційних джерел енергії, змінює розклад сил на енергетичних ринках, визначає економічне майбутнє країн. Серед різних видів альтернативних джерел енергії в Україні на провідних ролях перебуває біопаливо. У природному натуральному стані деревинна та рослинна біомаса є складним об'єктом для енергетичного використання. Технології виготовлення гранульованого та брикетованого біопалива забезпечують нормалізацію палива за гранулометричним станом та вологістю, підвищення об'ємної теплоти згоряння, змінюють логістику перевезень та зберігання. В Україні за останнє десятиліття створено понад 250 підприємств виробництва твердого біопалива (Snyezhkin, et al., 2014), з яких більшість підприємств продуктивністю до 1 т/год. За даними промисловості, виробництво та споживання біопалива не узгоджені в річному циклі, оскільки саме на зимовий період припадає як пік споживання, так і спад виробництв (Snyezhkin, et al., 2014). Зміни температурних режимів пресування, відсутність кліматичної стабілізації сировини за температурою перед пресуванням призводять до зменшення продуктивності ліній та роблять виробництво нерентабельним. Впливає на виробництво і зміна сировинної бази. Використання дешевої сировини забезпечує зниження собівартості біопалива, але потребує пошуку нових оптимальних режимів пресування. Розроблення енергоефективних режимів пресування та заходів енергозбереження в умовах виробництва матиме мультиплікативний ефект. Зниження енерговитрат на одиницю біопалива за заданих параметрів густини або міцності зменшує собівартість продукції, дає змогу забезпечити підвищену продуктивність виробничої лінії, зменшує знос обладнання. Розвиток наукових основ енергозбереження та вдосконалення технології виробництва твердих біопалив забезпечить сталий розвиток біоенергетичної галузі.

Аналіз літературних джерел. Проблему пресування деревини досліджували зі середини XX ст. (Modin, 1971; Homonai, 2006; Klimenko, 2017). Виробництво гранульованого біопалива з'явилося відносно недавно, близько середини 90-х років XX ст. у США. Основні наукові роботи зарубіжних вчених (Christofer Rhén et al., 2005, Sudhagar Mani et al., 2006; Dan Bergström et al., 2008; Carrie Yee Ching Jonsson, 2009; Wu Kai et al., 2010; Shi Shuijuan et al., 2012) стосуються гранулюван-

Інформація про авторів:

Корінчук Дмитро Миколайович, канд. техн. наук, пров. наук. співробітник, відділ тепломасопереносу в теплотехнологіях. Email: Korinchuk@nas.gov.ua; https://orcid.org/0000-0001-7752-4345

Цитування за ДСту: Корінчук Д. М. Вплив температурної та фізико-механічної активації біомаси на енерговитрати процесу пресування біопалив деревинного та рослинного походження. Науковий вісник НЛТУ України. 2018, т. 28, № 5. С. 111-118.

Citation APA: Korinchuk, D. M. (2018). Influence of temperature and physical and mechanical activation of biomass on energy consumption in pressing biofuels from wood and agricultural raw materials. Scientific Bulletin of UNFU, 28(5), 111-118. https://doi.org/10.15421/40280524 
ня деревини та відходів іiї перероблення. Проблему гранулювання рослинної біомаси на сьогодні розкрита лише в роботах (Kuchinskas, 1988; Osobov, 2009; Klimenko, 2017), які стосуються здебільшого гранулювання комбікормів і трав'яної муки. Значна кількість наукових робіт у галузі пресування біомаси присвячена розробці та модернізації конструкцій пристроїв гранулювання, але досі відсутні науково обгрунтовані узагальнені режими пресування, що змушує операторів практично вручну підбирати режими пресування окремих видів біопалива. Критерієм узагальнення режимів пресування різних видів біомаси можуть бути питомі витрати механічної енергії на утворення твердого біопалива заданої густини або потребна енергія пресування (Fedorenko \& Sadov, 2014).

У межах нових стандартів Європи EN 14961-1 насипна густина твердого гранульованого біопалива входить до основних параметрів, що нормуються. Мінімальне значення насипної густини становить $550 \mathrm{\kappa г} / \mathrm{m}^{3}$, що під час врахування порозності зернистого шару гранул, як тіл циліндричної форми (Kasatkin, 1973) в межах $35 \%$, має відповідати мінімальній об'ємній або

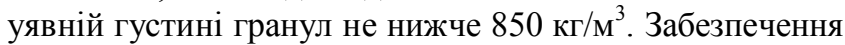
сталих параметрів енергоспоживання процесу пресування для різних видів біомаси потребує виявлення та дослідження чинників впливу на густину гранул та мінімізацію енерговитрат процесу пресування. Витрати енергії на пресування біопалива залежать переважно від фізико-механічних властивостей матеріалу, що переробляється, при цьому необхідно знати основні закономірності процесу пресування, які мають визначальне значення для процесу гранулоутворення. У межах колоїдної теорії гранулоутворення, яку обгрунтував Г. Агде, молекулярної теорії, що висунув В. Н. Наумович, та теорії водородних зв'язків, розробив А. Д. Чмир, гранулоутворення забезпечується внаслідок молекулярних зшивок колоїдних частин, макромолекул та в деяких випадках утворення водневих зав'язків за достатнього зближення поверхонь частин матеріалу. Робота тиску витрачається на деформацію матеріалу, видалення повітря 3 пор та зближення поверхонь частин до рівня молекулярної взаємодії. Густину та міцність гранул визначають сили молекулярного зв'язку, які пропорційні кількості вільної енергії контактуючих поверхонь, а відповідно, кількості утворених молекулярних контактів та зворотно-пропорційні розміру контактуючих часток. В умовах виробництва біопалива зменшити питомі енерговитрати на процес пресування можна способом підвищення активності на поверхні частин біомаси реакційних груп геміцелюлози, целюлози та лігніну, що входять до складу біомаси (Kindzera, et al., 2016). Цей ефект досягається методами температурної, хімічної або фізико-механічної активації (Ermolin, Bayandin \& Kazitsin, 2016). До зазначених методів відносять використання хімічних в'яжучих добавок (Sycheva, Khmyzov \& Solovyeva, 2013), використання підвищених температурних режимів (Bayandin, Ermolin \& Eliseev, 2013; Shtefan \& Ryndyuk, 2010; Ermolenko, et al., 2009) та розмелу сировини до рівня руйнування клітинної структури. Підвищення температури пресування призводить до активації на поверхні частин деревини реакційних груп, що сприяє утворенню нових молекулярних зв'язків та підвищенню густини гранул (Bayandin, Ermolin \& Eliseev, 2013). Результати дослідження оптимального темпе- ратурного режиму пресування представлені в працях (Bayandin, Ermolin \& Eliseev, 2013; Zavinskiy, et al., 2012) та мають істотні розбіжності. У роботі (Shtefan \& Ryndyuk, 2010) встановлено, що підвищення температури пресування біомаси вище $100{ }^{\circ} \mathrm{C}$ не доцільно, оскільки не веде до збільшення щільності. У роботі (Ermolenko, et al., 2009) обрано оптимальним інтервал температур $120-135{ }^{\circ} \mathrm{C}$. У роботі (Zavinskiy, et al., 2012) встановлено, що оптимальна температура для пресування деревини знаходиться в діапазоні 200-250 ${ }^{\circ} \mathrm{C}$. Розбіжності в дослідних даних потребують докладнішого дослідження впливу температури пресування на густину гранул та роботу пресування. У роботі (Sycheva, Khmyzov \& Solovyeva, 2013) досліджено режими хімічної активації деревини $з$ добавкою альбуміна, казеїна та крохмалю, з метою підвищення реакційної здатності компонентів біомаси, які під сумісною дією тиску та температури пластифікуються та набувають властивостей в'яжучого, що забезпечує високі адгезійні властивості взаємодії частин біомаси. Але хімічна активація біомаси не забезпечує задовільні фізико-механічні властивості всіх гранул через складність рівномірного оброблення всієї біомаси.

Дослідження фізико-механічної активації (Ermolin, Bayandin \& Kazitsin, 2016; Ermolenko, et al., 2009; Matus, et al., 2014; Bayandin, et al., 2015) зводилися до встановлення ефектів зниження енерговитрат та підвищення якісних показників пресованого матеріалу під час зменшення розміру подрібненої монофракційної сировини, поліфракційні суміші не досліджували. У роботах зазначено, що фізико-механічна активація частин біомаси приводить до збільшення вільної енергії на їх поверхні, що веде до інтенсифікації утворення молекулярних зав'язків під час пресування. Використання методу для зниження енерговитрат у промислових умовах виробництва твердого біопалива потребує додаткових досліджень поліфракційних сумішей біомаси.

Метою роботи $\epsilon$ визначення впливу температурної та фізико-механічної активації біомаси на витрати питомої енергії пресування біопалив деревинного та рослинного походження.

Об'єктом дослідження $є$ процеси пресування сировини деревинного та рослинного походження на прикладі тріски сосни, соломи та лузги соняшника заданого фракційного складу (табл. 1).

Табл. 1. Фракційний склад та насипна вага біомаси.

\begin{tabular}{|c|c|c|c|c|c|}
\hline \multirow{3}{*}{ Вид біомаси } & \multicolumn{4}{|c|}{ Фракційний склад матеріалу } & \multirow{3}{*}{$\begin{array}{c}\text { Насипна } \\
\text { густина } \rho_{0}, \\
{\text { кг } / \mathrm{M}^{3}}^{3}\end{array}$} \\
\hline & \multicolumn{4}{|c|}{$\begin{array}{c}\text { діапазон та середній розмір } \\
\text { фракції, мм }\end{array}$} & \\
\hline & $\begin{array}{c}0-0,315 \\
(0,2)\end{array}$ & $\begin{array}{c}0,315-2 \\
(1)\end{array}$ & $\begin{array}{c}2-5 \\
(3,5)\end{array}$ & $\begin{array}{l}5-10 \\
(7,5)\end{array}$ & \\
\hline Тріска сосни & 0,09 & 0,48 & 0,32 & 0,11 & 160 \\
\hline Солома & 0,12 & 0,46 & 0,27 & 0,15 & 125 \\
\hline Лузга соняшника & 0,08 & 0,36 & 0,38 & 0,18 & 120 \\
\hline
\end{tabular}

Матеріали і методи дослідження. В основу методики визначення енерговитрат пресування покладено положення, що під час пресування в закритій матриці енерговитрати на пресування відповідають роботі, яка витрачається на переміщення пуансона до утворення гранули заданої густини. Враховуючи масу матеріалу та визначивши залежність тиску пресування від ступеня ущільнення або приросту густини (рис. 1), можна визначити питому потребну роботу пресування для отримання гранул необхідної густини: 


$$
A_{\text {num }}=\frac{S}{M} \int_{0}^{z} \frac{\partial P(z)}{\partial z} d z,
$$

де: $P(z)$ - залежність тиску пресування від приросту густини, МПа; $z=\frac{\rho_{0}-\rho}{\rho}=\frac{x}{l_{0}-x}=\frac{\varepsilon}{1-\varepsilon}-$ приріст густини; $M$ - маса матеріалу, кг; $S$ - площа перерізу пуансона, $\mathbf{m}^{2} ; l_{0}$ - початкова товщина шару біомаси, $\rho_{0}-$ на-

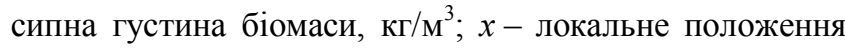
пуансона; $\varepsilon=\frac{x}{l_{0}}=\frac{\rho}{\rho_{0}}-$ відносне переміщення пуансона.
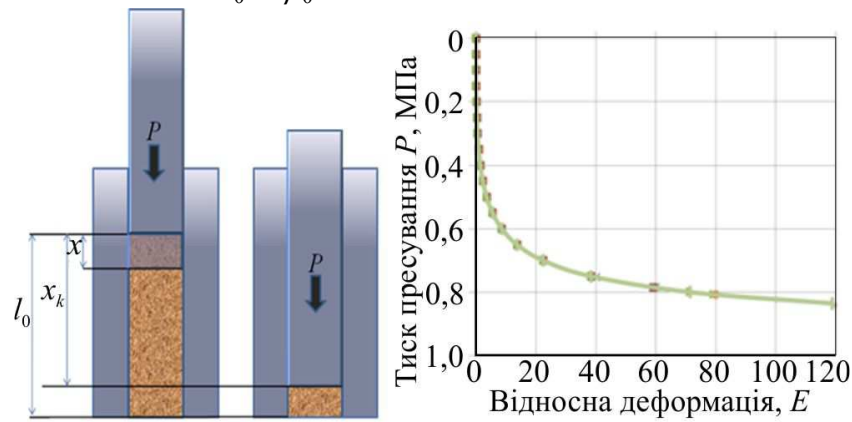

Рис. 1. Схема пресування в закритій матриці

Під потребною роботою розуміємо необхідну кількість підведеної енергії пресування для отримання гранул заданої густини. Величина потребної роботи залежить від умов проведення процесу і властивостей матеріалу та можна використати як критерій енергоефективності процесу пресування для отримання біопалива заданої якості.

Для розв'язання рівняння (1) використовували методи теорії пресування (Fedorenko, 2013). Залежність тиску $\frac{\partial P(z)}{\partial z}$ згідно з (Fedorenko, 2013) можна представити таким диференційним рівнянням:

$$
\frac{d P(z)}{d z}=m \frac{P}{z} .
$$

Розділивши змінні, проводимо потенціювання та інтегрування рівняння (2) і переходимо до основного рівняння пресування, вираженого у степеневій формі:

$$
P=P_{0}(z)^{m} \text { або } P=P_{0}\left(\frac{\varepsilon}{1-\varepsilon}\right)^{m},
$$

де $P_{0}$ i $m$ - коефіцієнти, що характеризують технологічні властивості вихідного матеріалу. Коефіцієнт $m$ має безрозмірний вид і характеризує форму кривої пресування. Коефіцієнт $P_{0}$ має розмірність тиску (МПа). За фізичною суттю коефіцієнт $P_{0}$ відповідає тиску, потребному для досягнення відносного збільшення густини $z=1$. Питому потребну роботу пресування $A_{\text {num }} 3$ урахуванням рівняння (2) та (3) можна представити наступним виразом:

$$
\begin{gathered}
A_{\text {num }}=\frac{P_{0} \cdot S}{M} \int_{0}^{x_{k}}\left(\frac{x}{l_{0}-x}\right)^{m} d x=\frac{P_{0} \cdot S \cdot l_{0}}{M} \frac{P_{0}}{\rho_{0}} \int_{0}^{\varepsilon_{k}}\left(\frac{\varepsilon}{1-\varepsilon}\right)^{m} d \varepsilon= \\
=\frac{P_{0}}{\rho_{0}} \int_{0}^{\varepsilon_{k}}\left(\frac{\varepsilon}{1-\varepsilon}\right)^{m} d \varepsilon
\end{gathered}
$$

де $d x=l_{0} d \varepsilon$ - перемішення пуансона, м; $M=S \cdot l_{0} \cdot \rho_{0}$ маса матеріалу в матриці, кг.

Методика визначення коефіцієнтів $P_{0}$ та $m$, включає експериментальне дослідження та побудову компресійних характеристик пресування окремих видів біомаси виду $P=f(\varepsilon)$ (див. рис. 1). Апроксимація компре- сійних характеристик лінійним рівнянням виду $y=a x+b$ в логарифмічних координатах та зіставлення залежності 3 логарифмічним виразом рівняння (3) $\ln (P)=\ln P_{0}+m \ln \left(\frac{\varepsilon}{1-\varepsilon}\right)$ дає змогу визначити параметри, що характеризують технологічні властивості вихідного матеріалу: $m=a, P_{0}=E X P(b)$.

Для визначення компресійної характеристики пресування дисперсних матеріалів створено дослідну установку на базі розривної машини типу МР100 (рис. 2).

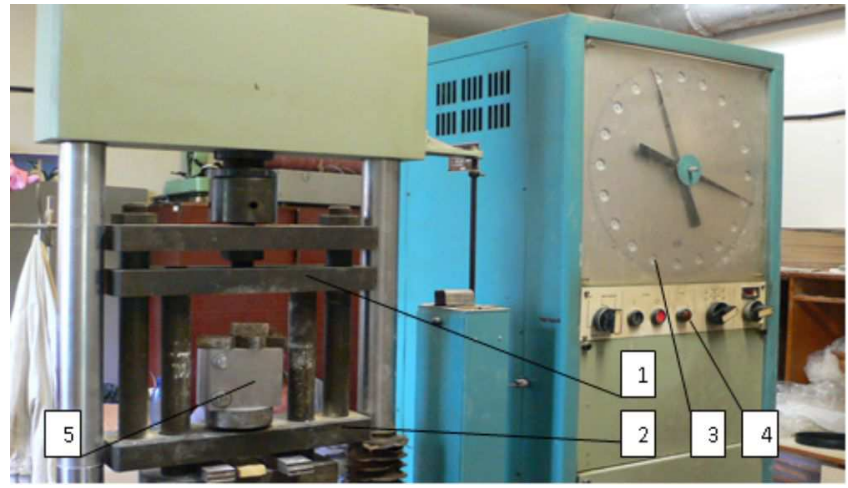

Рис. 2. Схема дослідної установки: 1) рухома плита; 2) опірна плита; 3) вимірювач сили; 4) пульт керування; 5) пристрій для пресування

Дослідна установка включала вимірювач сили 3, з'єднаний 3 механічним приводом верхньої рухомої плити 1 гідравлічною мережею, що утворює замкнену гідравлічну систему та дає змогу визначити зусилля пресування. Циферблат вимірювача має дві стрілки, що показують локальний та максимальний тиск за період дослідження. Максимальне зусилля пресування становить 120 кН. Похибка визначення сили брикетування становить $\pm 0,2$ кН. Пристрій для брикетування 5 - це розбірна матриця та пуансон для пресування сировини в гранули 3 розмірами $20 \times 50$ мм.

Методика пресування гранул. Перед пресуванням згідно з ISO 1953 визначали фракційний склад матеріалу (див. табл. 1) методом ситового аналізу. Матеріал підсушували за температури сушильного агенту 250$260{ }^{\circ} \mathrm{C}$ до вологості 8-10\%. На стадії дослідження фізико-механічної активації частину матеріалу перед пресуванням подрібнювали до середнього розміру 200 мкм, після чого формували суміш цього виду біомаси з масовим вмістом мікрофракції 10-30 \%, 50 \%.

Згідно з планом експерименту готували наважку заданого виду біомаси. Масу наважки визначали шляхом зважування на лабораторних вагах Axis 500 AD. У першій серії досліджень температурної активації біомаси підготовлений матеріал підігрівали паралельно з матрицею до заданої температури в сушильній шафі. Температуру матеріалу контролювали пірометром testo 830 $\mathrm{T}_{1}$, абсолютна похибка за результатами вимірювань не перевищувала $\pm 1,5^{\circ} \mathrm{C}$. Після досягнення заданої температури матрицю заповнювали матеріалом та встановлювали в центральній частині опірної плити після чого відбувалося пресування. Швидкість переміщення рухомої плити становила 0,02 м/хв. Зусилля пресування фіксували за відповідним положенням стрілки вимірювача сили. Після досягнення заданого зусилля навантаження матеріал витримували під тиском 5 с, після чого навантаження знімали, рухому плиту підіймали у верхнє положення. Видаляли брикет із матриці внаслідок виш- 
товхування пуансоном. Густину визначали після вилучення брикета з матриці шляхом його обміру штангенциркулем, зважування та наступних розрахунків. За результатами трьох паралельних дослідів розраховували середнє арифметичне значення густини гранул. Абсолютна похибка визначення густини гранул не переви-

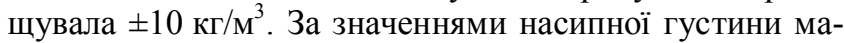
теріалу та густини гранул розраховували відносне переміщення пуансона.

Пружне розширення визначали як різницю висоти брикета та граничного положення пуансона. У дослідженнях пружне розширення не перевищувало $10 \%$, максимум відповідав мінімальному тиску та температуpi. У розрахунках потребної роботи не враховували частку роботи пружних деформацій. Максимальна відносна похибка розрахунку потребної роботи становила 5 \%.

Другу серію досліджень фізико-механічної активації проводили в аналогічній послідовності, за винятком стадії прогріву матеріалу.

Результати дослідження та їх обговорення. 3 розробленої методики проведення експерименту отримано комплекс даних, що характеризують процес пресування біомаси деревного та рослинного походження, включаючи роботу пресування та густину гранульованого палива разом із тиском і температурою пресування та тиском і вмістом мікрофракції.

Математичну обробку результатів експерименту проводили з використанням математичних пакетів Ехcel, OriginLab та алгоритму модифікованого методу локальної апроксимації Шепарда для побудови поверхонь відклику густини та питомої потребної роботи пресування.

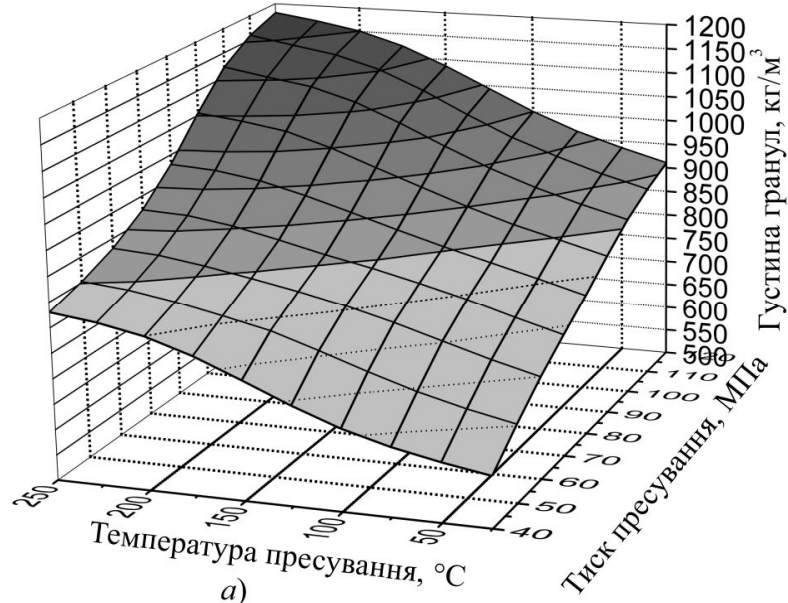

a)

Рис. 3. Вплив температури та тиску пресування біомаси сосни на: а) густину гранул; б) енерговитрати процесу

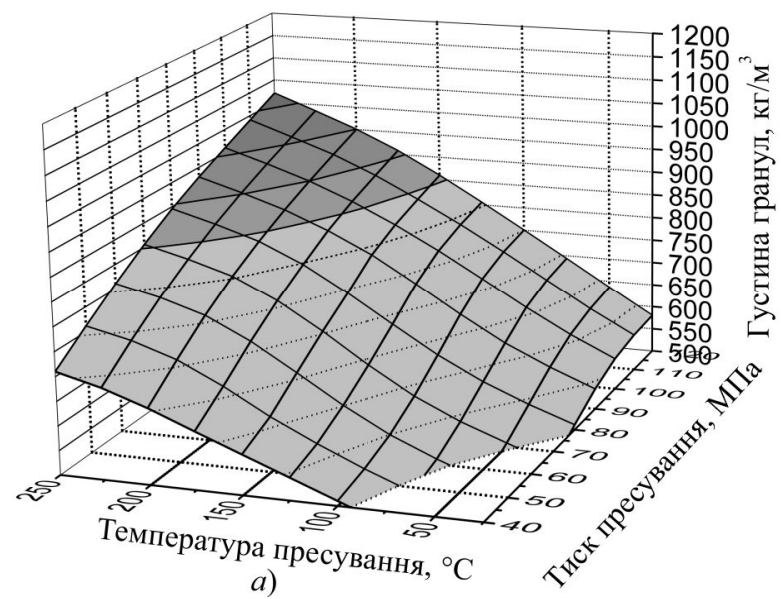

На рис. 3-5 (а) представлено графіки залежностей густини зразків (гранул) від тиску пресування та температури сировини для тріски сосни, соломи і лушпиння соняшника. Залежність має нелінійний характер, максимальну інтенсивність зростання густини гранул спостерігаємо на ділянках від 60 МПа до 100 МПа, що відповідає в середньому $6,5-7$ кг/(м³

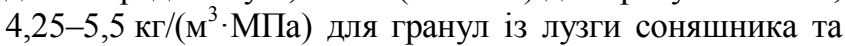
соломи. У межах досліджуваного діапазону внаслідок збільшення тиску пресування від 40 МПа до 120 МПа зростання густини становить 47 \% для всіх видів досліджуваної біомаси. Підвищення температури сировини веде також до інтенсивного зростання густини. У температурному інтервалі від $100{ }^{\circ} \mathrm{C}$ до $200{ }^{\circ} \mathrm{C}$ інтенсивність зростання густини становить для гранул із сосни 1$1,4 \mathrm{\kappa г} /\left(\mathrm{M}^{3} \cdot{ }^{\circ} \mathrm{C}\right)$ та $2,0-2,2 \mathrm{\kappa r} /\left(\mathrm{M}^{3} \cdot{ }^{\circ} \mathrm{C}\right)$ для гранул 3 соломи та лузги соняшника. У межах досліджуваного діапазону температур під час збільшення температури пресування $325{ }^{\circ} \mathrm{C}$ до $250{ }^{\circ} \mathrm{C}$ зростання густини становить у середньому $23 \%$ для сосни, $73 \%$ для соломи та лузги соняшника, під час зменшення потребної роботи пресування на $23 \%$ - 46 та $32 \%$ відповідно. Використання температурного режиму вище $200{ }^{\circ} \mathrm{C} \epsilon$ недостатньо обгрунтованим, оскільки незначному приросту густини будуть відповідати досить великі енергетичні витрати на нагрів матеріалу. У виробничих умовах цей процес супроводжується істотним газовиділенням, втратою сухої маси і хоча, згідно з (Snezhkin, Korinchuk \& Bezhin, 2017), теплота згоряння біопалива підвищується, для реалізації процесу високотемпературного пресування необхідно розробляти спеціальне обладнання.

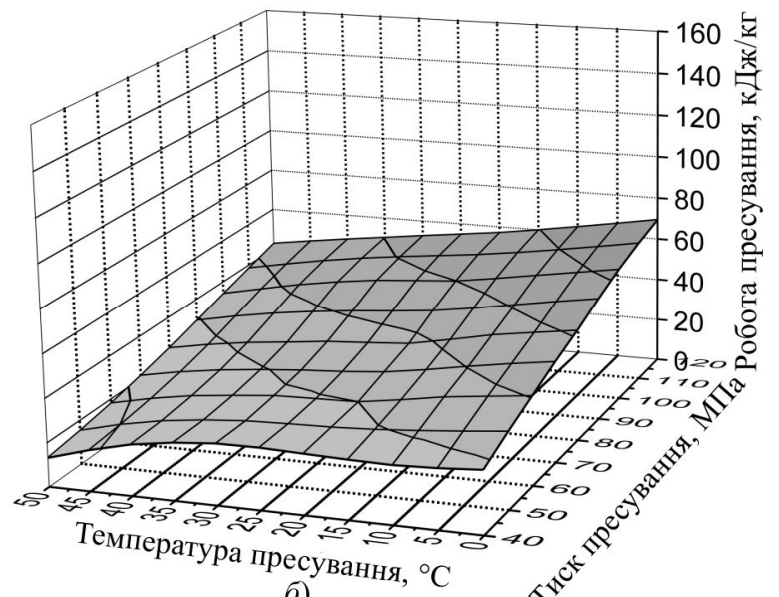

б) ергвитрати процесу

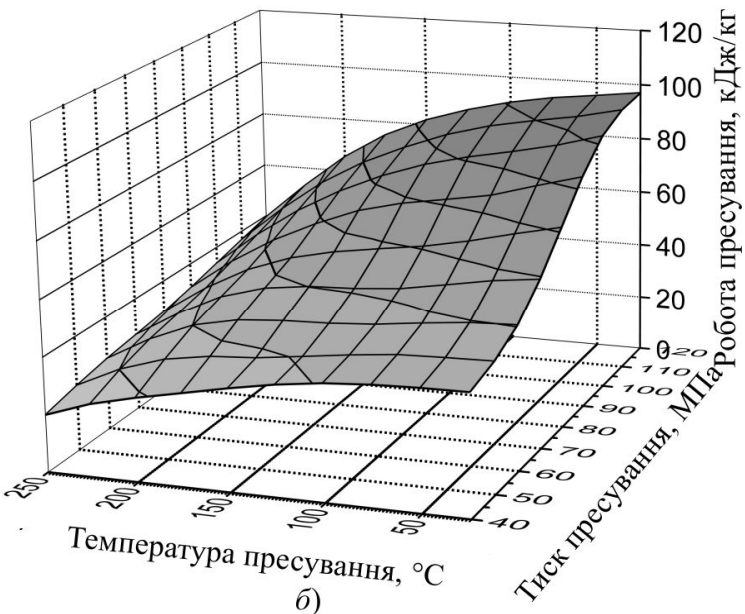

б)

Рис. 4. Вплив температури та тиску пресування біомаси соломи на: а) густину гранул; б) енерговитрати процесу 


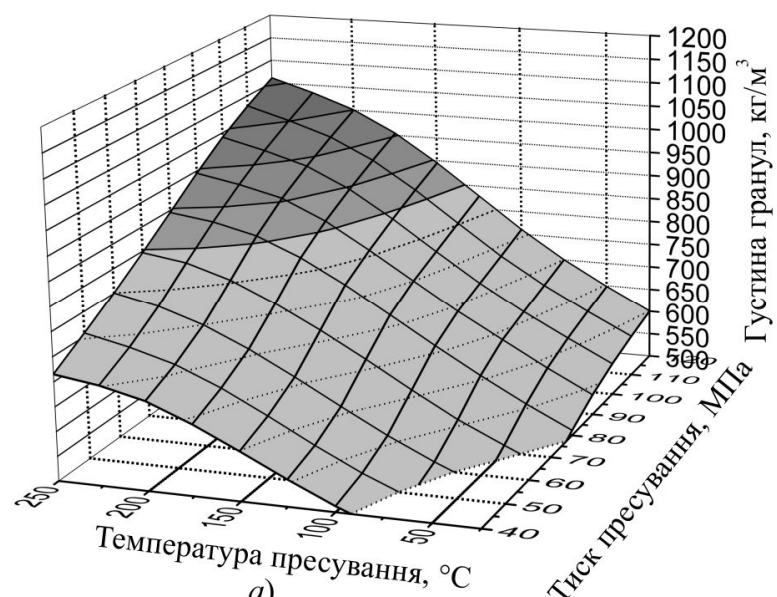
a)

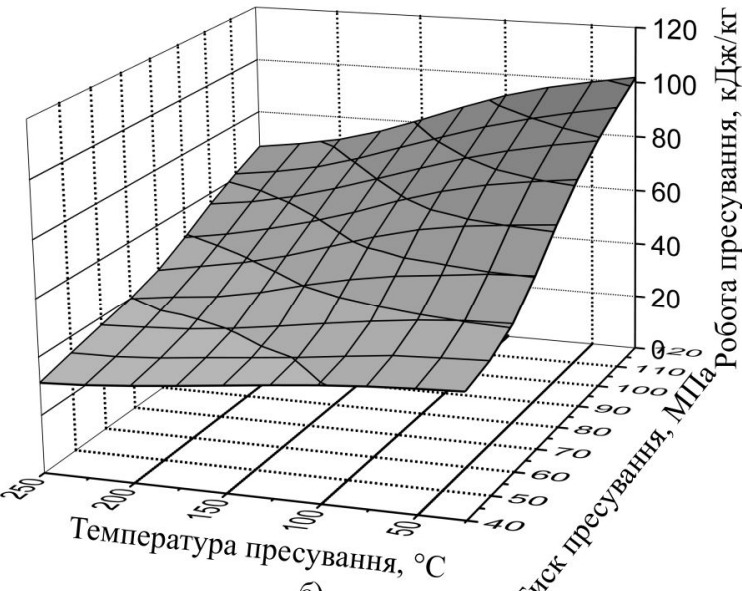

б)

Рис. 5. Вплив температури та тиску пресування біомаси лузги соняшника на: а) густину гранул; б) енерговитрати процесу

3 рис. 3-5 (а) видно, що поле існування гранул, які відповідають нормованим умовам об'ємної густини, обмежено комбінацією тиску та температури у межах затемненої області. Для деревинних гранул отримання гранул в межах нормованого значення густини забезпечується дотриманням режиму пресування за тиску пресування вище $80 \mathrm{MПа} \mathrm{та} \mathrm{температури} \mathrm{вище}$ $100{ }^{\circ} \mathrm{C}$. Спостерігаємо звуження зазначеного діапазону під час переходу з деревинного матеріалу на рослинну сировину. За результатами досліджень можна рекомендувати підтримування для рослинної біомаси режиму в межах тиску пресування вище 100 МПа та температури не нижче $150^{\circ} \mathrm{C}$. Внаслідок зменшення температури або тиску необхідно підвищувати значення іншого параметра. Забезпечення тиску пресування потребує підвищення витрат енергії пресового обладнання, що не завжди можливо в межах встановленої потужності обладнання. Відповідно підвищення потребної питомої роботи пресування зі зниженням температури сировини внаслідок зміни кліматичних умов або зміни властивостей та виду сировини призведе до зменшення продуктивності лінії, погіршення якості продукту, втрат сировинного ресурсу та відмов обладнання.

3 метою обгрунтування енергоефективних режимів роботи проведено аналіз питомої роботи пресування деревинної та рослинної сировини з використанням температурної та фізико-механічної активації матеріалу в межах досліджуваного діапазону зміни тиску пресування.

За результатами математичного оброблення компресійних кривих для різних видів біомаси визначено залежності параметрів $P_{0}$ та $m$ від температури пресування (табл. 2). 3 використанням даних табл. 2 та рівняння (4) розраховано значення питомої потребної роботи пресування. Аналіз графічних залежностей (див. рис. 3$5, б)$ показав, що зі збільшенням тиску пресування в діапазоні 40-120 МПа енерговитрати на процес зростають для гранул із деревини сосни, соломи та лузги соняшника відповідно в 2,44, 2,37 та 2,25 раза. Підвищення температури пресування від 20 до $250{ }^{\circ} \mathrm{C}$ веде до зменшення питомих енерговитрат у середньому для гранул 3 деревини сосни, соломи та лузги соняшника відповідно на 23, 46 та $32 \%$. Результати дослідження підтверджують безпосередній вплив температурного режиму на енерговитрати пресування та необхідність забезпечення сталого температурного режиму пресування та жорсткого його контролю на виробництві. Під час переходу з деревинної сировини на рослинну біома- су необхідно враховувати потужність обладнання та забезпечувати, згідно із запропонованими методиками та залежностями (див. рис. 3-5, а,б; табл. 2), зменшення величини потребної роботи пресування способом суміщення регулювання тиску пресування та температурного режиму в межах поля існування гранул не нижче нормованої густини. Характер залежності потребної роботи пресування від температурного режиму робить обгрунтованим наявність у схемі виробництва ділянки температурної активації матеріалу перед пресуванням, що дасть змогу витримувати температурний режим пресування, забезпечить мінімальні енерговитрати пресового обладнання та цілорічну сталу продуктивність ліній виробництва біопалива.

Табл. 2. Залежності коефіціснтів основного рівняння пресування від температури

\begin{tabular}{|c|c|c|c|}
\hline \multirow{2}{*}{\multicolumn{2}{|c|}{ Матеріал }} & \multicolumn{2}{|c|}{$\begin{array}{c}\text { Залежності для визначення коефіцієнтів } \\
\text { основного рівняння пресування }\end{array}$} \\
\hline & & $P_{0}$ & $m$ \\
\hline \multirow[t]{2}{*}{1} & \multirow{2}{*}{ Сосна } & $\begin{aligned} P_{0}=0,000032 t^{2}-0,022 t \\
+4,67\end{aligned}$ & $m=0,0015 t+2,014$ \\
\hline & & $R^{2}=0,99$ & $R^{2}=0,98$ \\
\hline \multirow[t]{2}{*}{2} & \multirow[t]{2}{*}{ Солома } & $\begin{array}{c}P_{0}=0,00016 t^{2}-0,0775 t \\
+10,0\end{array}$ & $m=0,0031 t+1,824$ \\
\hline & & $R^{2}=1$ & $R^{2}=0,98$ \\
\hline \multirow[t]{2}{*}{3} & \multirow[t]{2}{*}{ Лузга } & $\begin{array}{c}P_{0}=0,00014 t^{2}-0,067 t \\
+8,87\end{array}$ & $m=4,53 t^{2}-3,63 t+1,99$ \\
\hline & & $R^{2}=1$ & $R^{2}=0,94$ \\
\hline
\end{tabular}

Підвищення реакційної здатності частин біомаси та зменшення питомої потребної роботи пресування можна досягти також фізико-механічною активацією способом тонкого подрібнення. У межах молекулярної теорії пресування інтенсифікація сил молекулярної взаємодії внаслідок тонкого подрібнення відбувається внаслідок руйнування на поверхні частин молекулярних структур, збільшення зовнішньої питомої поверхні та щільнішого розміщення частинок пресматеріалу. Останні два чинники ведуть до збільшення поверхні дотику та кількості молекулярних зшивок. Але суміщення фізико-механічної активації з наступним високотемпературним сушінням спричиняє термічну деструкцію поверхневого шару частин, що нівелює ефект підвищення реакційної здатності. Проведено дослідження щодо підвищення реакційної здатності матеріалу способом введення в нього мікрофракції біомаси вторинного подрібнення. Саме вторинне подрібнення дає змогу відновити реакційну активність матеріалу після термообробки в процесі сушіння. Активацію проводили способом відбору фіксованої частин матеріалу, подрібнення в молотковій дро- 
барці до середнього розміру 200 мкм та введення в суміш перед пресуванням. Процес пресування проводили за нормальної температури. За результатами досліджень розраховано коефіцієнти основного рівняння пресування (табл. 3) та побудовано залежності зміни густини гранул та роботи пресування від тиску та вмісту мікрофракції. Аналіз графічних залежностей (рис. 6$8, a, \sigma)$ дав змогу встановити, що максимальна інтенсивність зростання густини становить $20-25$ кг $/ \mathrm{M}^{3}$ на кож-

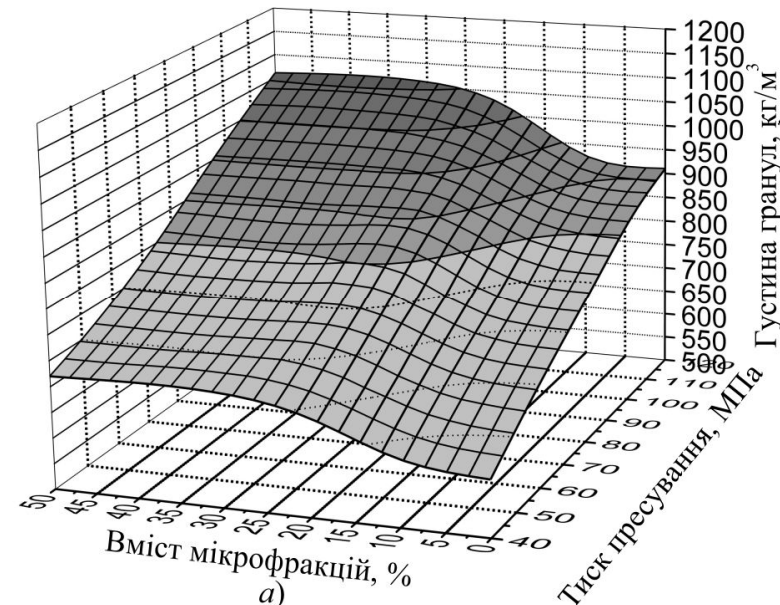

ний відсоток вмісту мікрофракції і відповідає вмісту мікрофракції до $20 \%$. Подальше збільшення вмісту мікрофракції не веде до істотного приросту густини гранул. Потребна робота пресування внаслідок введення активованої мікрофракції в суміш біомаси зменшується. За вмісту мікрофракції вище 20 \% робота пресування зменшується на 18-28 \%. Максимум відповідає діапазону пресування 60-100 МПа.

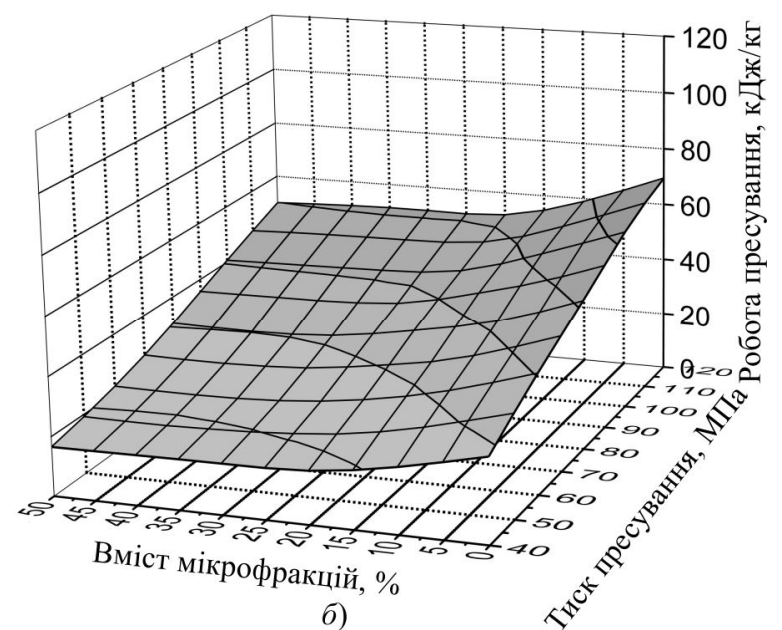

б)

Рис. 6. Вплив вмісту мікрофракції та тиску пресування біомаси сосни на: а) густину гранул; б) енерговитрати процесу
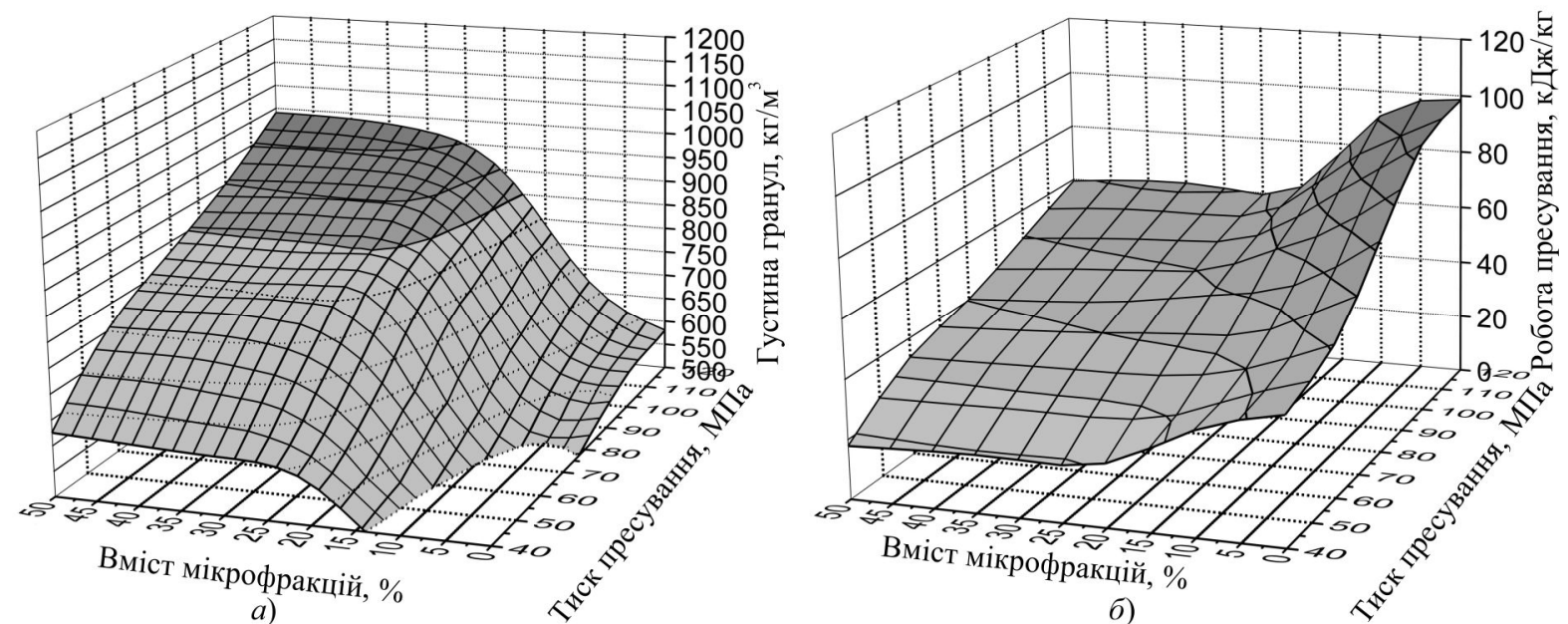

Рис. 7. Вплив вмісту мікрофракції та тиску пресування біомаси соломи на: а) густину гранул; б) енерговитрати процесу
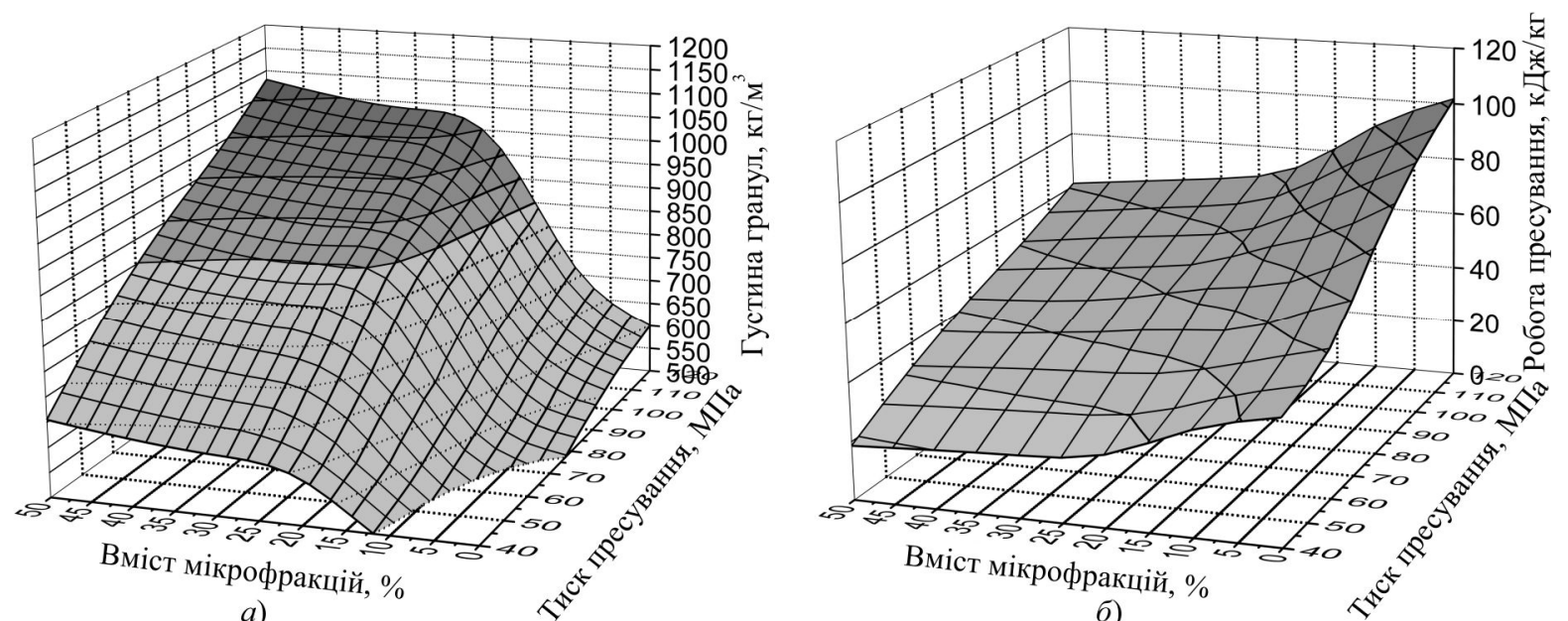

Рис. 8. Вплив вмісту мікрофракції та тиску пресування біомаси лузги соняшника на: а) густину гранул; б) енерговитрати процесу

Схожий вигляд рівнянь для визначення коефіцієнтів основного рівняння пресування залежно від вмісту мікрофракції (див. табл. 3) свідчить про однакові механізми впливу активованої мікрофракції різних видів біома- си на процес гранулоутворення. Отже, у композиційній суміші біомаси введення активованої мікрофракції одного виду біомаси в інший може зменшити потребну роботу пресування згідно з отриманими вище залеж- 
ностями та забезпечити гарантоване виробництво гранул нормованої густини.

Табл. 3. Залежності коефіцієнтів основного рівняння пресування від вмісту мікрофракції

\begin{tabular}{|c|c|c|c|}
\hline \multirow{2}{*}{\multicolumn{2}{|c|}{ Матеріал }} & \multicolumn{2}{|c|}{$\begin{array}{c}\text { Залежності для визначення коефіцієнтів } \\
\text { основного рівняння пресування }\end{array}$} \\
\hline & & $P_{0}$ & $\begin{array}{c}m \\
\end{array}$ \\
\hline & \multirow[t]{2}{*}{ Сосна } & $\begin{array}{c}P_{0}=-131,3 t^{2}+141,0 t+ \\
2,07\end{array}$ & $\begin{array}{c}m=1,85 t^{2}-1,85 t+ \\
2,08\end{array}$ \\
\hline & & $R^{2}=0,97$ & $R^{2}=0,97$ \\
\hline \multirow[t]{2}{*}{2} & \multirow{2}{*}{ Солома } & $\begin{array}{c}P_{0}=-194 t^{2}+158,0 t+ \\
9,33\end{array}$ & $m=3,99 t^{2}-2,92 t+1,9$ \\
\hline & & $R^{2}=0,97$ & $R^{2}=0,96$ \\
\hline & \multirow[t]{2}{*}{ Лузга } & $P_{0}=-164 t^{2}+154 t+5,79$ & $\begin{array}{c}m=4,53 t^{2}-3,63 t+ \\
1,99\end{array}$ \\
\hline & & $R^{2}=0,9$ & $R^{2}=0,9$ \\
\hline
\end{tabular}

Виявлені ефекти зменшення потребної роботи пресування в умовах температурної та фізико-механічної активації матеріалу цілком можна пояснити в межах молекулярної теорії пресування. Як відомо (Kindzera, et al., 2016), біомаса $є$ композиційним біополімером, що складається 3 довгих ланцюгів молекул, таких як: геміцелюлоза, целюлоза та лігнін. Внаслідок термічної та фізико-механічного оброблення частина ланцюгів розривається з утворенням вільних радикалів, що підвищує реакційну здатність біомаси до утворення молекулярних зав'язків. Термічна деструкція поверхні мікрофракції під час сушіння та охолодження, як було зазначено раніше, веде до зниження кількості вільної енергії на одиницю поверхні та реакційної здатності мікрофракції. Зважаючи на останнє припущення, можна рекомендувати організувати підготовку біомаси перед пресуванням за схемою (Korinchuk, 2018), у якій після стадії подрібнення настає стадія сушіння, після чого частина матеріалу не менше 20 \% за масою надходить на тонке подрібнення, змішується 3 основною масою, термічно активується та поступає на пресування.

Висновки. Експериментально-розрахунковим способом отримано залежності впливу температурного режиму, тиску пресування та вмісту мікрофракції на густину гранул біопалива та питому роботу пресування. Встановлено, що в межах досліджуваного діапазону тиску 40-120 МПа, температури $25-250{ }^{\circ} \mathrm{C}$ та вмісту активованої вторинним подрібненням мікрофракції біомаси в межах 0-50 \%, збільшення кожного параметра процесу веде до підвищення об'ємної густини гранул біопалива. Водночас підвищення тиску пресування веде до збільшення потребної роботи пресування у 2,2-2,4 раза, а температури та вмісту мікрофракції - до зменшення на $22-46$ та $18-28 \%$.

Результати дослідження підтверджують безпосередній вплив температурного режиму на енерговитрати пресування та необхідність забезпечення сталого температурного режиму пресування та його контролю на виробництві.

Встановлено ефект збільшення потребної роботи на пресування під час переходу від деревинної до рослинної біомаси. За результатами досліджень рекомендовано в технологіях виробництва твердого біопалива включати ділянки температурної та фізико-механічної активації. Для забезпечення температурного режиму пресування температурну активацію матеріалу перед пресуванням можна проводити за температури деревинної біомаси не нижче $100{ }^{\circ} \mathrm{C}$ та рослинної біомаси не нижче $150{ }^{\circ} \mathrm{C}$. Фізико-механічну активацію матеріалу реко- мендовано проводити способом подрібнення після стадії сушіння не менше 20 \% загальної маси матеріалу до мікрофракції з середнім розміром не більше 200 мкм 3 наступним змішуванням 3 основною масою та пресуванням, або введенням у матеріал мікрофракції біомаси іншого виду в тих же пропорціях.

\section{Перелік використаних джерел}

Bayandin, M. A., Ermolin, V. N., \& Eliseev, S. G. (2013). Vliyaniye mekhanoaktivatsii na autogezionnyye svoystva drevesiny. [Effect of mechanoactivation on the autohesive properties of wood]. Khvoynyye boreal'noy zony. [Coniferous boreal zone], 30(1-2), 159-163. [In Russian].

Bayandin, M. A., Yermolin, V. N., Kazitsin, S. N., \& Yeliseyev, S. G. (2015). Vliyaniye melkodispersnykh fraktsiy na formirovaniye svoystv drevesnykh plit bez svyazuyushchego. Khvoynyye boreal'noy zony, 33(3-4), 182-185. [In Russian].

Ermolenko, N. I., Khmyzov, I. A., Dubodelova, E. V., Solovieva, T. V., \& Maximuk, Yu. V. (2009). Issledovaniye vliyaniya tekhnologicheskikh faktorov i porodnogo sostava syr'ya na svoystva toplivnykh granul. [Investigation of the influence of technological factors and composition of raw materials on the properties of fuel pellets]. Proceedings of BSTU. Series: Chemistry, technology of organic substances and biotechnology, 1(4), 270-273. [In Russian].

Ermolin, V. N., Bayandin, M. A., \& Kazitsin, S. N. (2016). Mechanical Activation of Wood for Adhesive-free board Production. IOP Conference Series: Materials Science and Engineering, 155(1), 14. https://doi.org/10.1088/1757-899X/155/1/012038

Fedorenko, I. Ya. (2013). Alternativnaya teoriya pressovaniya kormov. Altai State Agricultural University Bulletin, 3(101), 95-98. [In Russian].

Fedorenko, I. Ya., \& Sadov, V. V. (2014). Optimization of feed pelleting and briquetting process in terms of energy costs. Altai State Agricultural University Bulletin, 2(112), 114-119. [In Russian].

Kasatkin, A. G. (1973). Basic processes and apparatus of chemical technology. Moscow: Chimia. 752 p. [In Russian].

Kindzera, D. P., Pelekh, M. P., Hosovskyy, R. R., \& Kindzera, A. R. (2016). Reducing energy costs during production of solid biofuel and improving quality of products. SCHMT, 841, 302-307. [In Ukrainian].

Korinchuk, D. M. (2018). Justification of energy consumption during the comminution stage in the technologies of biofuel production. Scientific Herald of NULES of Ukraine, 1(268), 90-100. [In Ukrainian].

Matus, M., Krizan, P., Soos, L., Beniak, J., \& Lisy, M. (2014). The influence of size fraction and moisture content on the compressibility of wood sawdust in effective process of production a solid biofuel. 14th SGEM Geo Conference on Energy and Clean Technologies, 1, 553-560.

Shtefan, Ye. V., \& Ryndyuk, D. V. (2010). Issledovaniye vliyaniya temperatury na protsess pressovaniya dispersnykh materialov. Bulletin of NTU "KhPI", 65, 114-118. [In Russian].

Snezhkin, Y. F., Korinchuk, D. M., \& Bezhin, M. M. (2017). Doslidzhennya rezhymiv termoobrobky biomasy ta torfu u vyrobnytstvi kompozytsiynoho biopalyva. [Investigation of regimes of heat treatment of biomass and peat in production and composite biofuels]. Industrial Heat Engineering, 39(1), 53-57.

Snyezhkin, Yu. F., Korinchuk, D. M., Bezhin, M. M., \& Stepchuk, I. V. (2014). Enerhetychnyy analiz tekhnolohiy vyrobnytstva tverdoho biopalyva. Naukovi pratsi ONAKHT [Scientific Works], 45(3), 187-190. [In Ukrainian].

Sycheva, N. A., Khmyzov, I. A., \& Solovyeva, T. V. (2013). Vliyaniye kompozitsionnogo sostava toplivnykh pellet na ikh pokazateli kachestva. Trudy BGTU. Series: Chemistry, technology of organic substances and biotechnology, 4(4), 182-184. [In Russian].

Zavinskiy, S. I., Telnov, I. A., Troshin, A. G., \& Moiseyev, V. F. (2012). Vliyaniye davleniya pressovaniya i temperatury na svoystva briketov iz drevesnoy struzhki. Bulletin of NTU "KhPI", 10, 144 149. [In Russian]. 


\title{
ВЛИЯНИЕ ТЕМПЕРАТУРНОЙ И ФИЗИКО-МЕХАНИЧЕСКОЙ АКТИВАЦИИ БИОМАССЫ НА ЭНЕРГОЗАТРАТЫ ПРОЦЕССА ПРЕССОВАНИЯ БИОТОПЛИВА ДРЕВЕСНОГО И РАСТИТЕЛЬНОГО ПРОИСХОЖДЕНИЯ
}

\begin{abstract}
Проведено экспериментальное исследование компрессионных характеристик прессования измельченной полифракционной биомассы растительного и древесного происхождения на примере древесины сосны, соломы и лузги подсолнечника. Установлены зависимости коэффициентов основного уравнения прессования от температуры прессования и содержания микрофракции вторичного измельчения. Определена плотность гранул, рассчитана удельная работа гранулообразования, исследованы закономерности их изменения при повышении давления, температуры и содержания микрофракции. Установлено, что в пределах исследуемого диапазона увеличение давления, температуры и содержания микрофракции вторичного измельчения ведет к увеличению объемной плотности гранул биотоплива. В то же время повышение давления прессования ведет к увеличению удельной работы прессования в 2,2-2,4 раза, а температуры и содержания микрофракции - к уменьшению на 22-46 \% и 18-28\%. Установлен эффект увеличения удельной работы прессования при переходе от древесной биомассы к растительной. Рекомендовано в технологиях производства твердого биотоплива включать участки температурной активации материала перед прессованием с целью обеспечения температурного режима прессования не ниже $100{ }^{\circ} \mathrm{C}$ для древесной биомассы и не ниже $150{ }^{\circ} \mathrm{C}$ для растительной биомассы, а также участки физико-механической активации материала путем тонкого измельчения после стадии сушки не менее $20 \%$ общей массы материала до микрофракции со средним размером не более 200 мкм с последующим смешиванием с основной массой и прессованием или введением в биомассу микрофракции биомассы другого вида в тех же пропорциях.
\end{abstract}

Ключевые слова: работа прессования; энергоэффективные режимы; микрофракция; давление; плотность.

\author{
D. M. Korinchuk \\ Institute of Engineering Thermophysic, NAS Ukraine, Kyiv, Ukraine
}

\section{INFLUENCE OF TEMPERATURE AND PHYSICAL AND MECHANICAL ACTIVATION OF BIOMASS ON ENERGY CONSUMPTION IN PRESSING BIOFUELS FROM WOOD AND AGRICULTURAL RAW MATERIALS}

The fluctuations of the temperature modes of pressing, the lack of climatic temperature stabilization of raw materials before pressing, the change in the properties of the raw material base leads to an increase in the specific energy consumption of the process; and causes a decrease in the profitability of biofuel production and the discrepancy between annual production peaks and consumption of solid granular biofuels. Therefore, the work is devoted to the development of energy-efficient compression modes and energy saving measures in the production of granular biofuels. The aim of this work is to determine the influence of temperature and physical-mechanical activation of biomass on the energy consumption for pressing biofuels of wood and plant origin. We selected biomass of pine, sunflower husk and straw after the stages of shredding and drying as the research objects. The dependences of the compressive characteristics of biomass on compression pressure, temperature and content of microfraction were experimentally obtained; the dependences of the coefficients of the basic equation of compression on the temperature and content of microfraction of secondary crushing were determined by the method of linear approximation of experimental curves in logarithmic coordinates. The compression work at the studied modes is calculated. The analysis of the dependences of biofuel density and compression work has shown that an increase of the pressure, temperature and content of microfraction of secondary grinding within the studied range leads to an increase in the volume density of biofuel pellets. At the same time, the pressure increase leads to an increase in the specific compression work in 2.2-2.4 times, and to decrease in the temperature by $22-46 \%$ and content of microfraction by $18-28 \%$. The effect of increasing the specific work for pressing during the transition from wood to plant biomass has been established. It is recommended to include areas of temperature and physical-mechanical activation in solid biofuel production technologies. To ensure the temperature regime of pressing, the temperature activation of the material before pressing should be carried out at a temperature of wood biomass not lower than $100^{\circ} \mathrm{C}$ and for plant biomass not lower than $150^{\circ} \mathrm{C}$. Physical-mechanical activation of the material should be carried out by grinding after the drying stage of at least $20 \%$ of the total mass of the material to the microfraction with an average size of no more than 200 micron, followed by mixing with the base mass and compressing or entering microfraction of another species in the same proportions into material.

Keywords: compression work; energy-efficient modes; microfraction; pressure; density. 